\title{
特＼cjkstart集 「今日からの診療に役立つアレルギー疾患の診断・治療の最新情報」
}

\section{アレルギー性鼻炎と好酸球性副鼻腔炎の診断・治療の最新情報}

\author{
永田 善之 野村 泰之 \\ 日本大学医学部附属板橋病院耳鼻咽喉・頭頸部外科学分野
}

\author{
Latest Information on the Diagnosis and Treatment \\ of Allergic Rhinitis and Eosinophilic Chronic Rhinosinusitis \\ Yoshiyuki NaGata and Yasuyuki NomURA \\ Department of Otolaryngology-Head and Neck Surgery, Nihon University School of Medicine, Tokyo Japan
}

\begin{abstract}
Research on the pathophysiology of airway mucosal disease has been dramatically advanced by recent progress in immunology in the past few decades. In ARIA (Allergic Rhinitis and its Impact on Asthma), the similarity and relevance of the mucosal pathology of the upper and lower respiratory tracts has been pointed out. Even otolaryngologists, who often treat upper respiratory diseases, need to understand and treat lower respiratory diseases, which have a similar pathophysiology. Allergic rhinitis and eosinophilic chronic rhinosinusitis are noted allergic diseases in the field of otorhinolaryngology, and both are associated with lower respiratory tract diseases (particularly bronchial asthma). In this article, we describe the pathologies and treatments of allergic rhinitis and eosinophilic chronic rhinosinusitis.
\end{abstract}

Key words: allergic rhinitis, eosinophilic chronic rhinosinusitis, airway mucosal disease, eosinophilic airway inflammation アレルギー性鼻炎, 好酸球性副鼻腔炎, 気道粘膜疾患, 好酸球性気道炎症

(J. Nihon Univ. Med. Ass., 2020; 79 (2): 87-92)

\section{はじめに}

アレルギー性鼻炎は本邦において成人のほぼ半数が罹 患していると言われている．現在もな抒罹患患者数は増 加傾向で，発症の低年齢化が問題となっている，近年， ARIA (Allergic Rhinitis and its Impact on Asthma) に扔い て, 上気道と下気道の粘膜病態の類似性と相互の関連性 が指摘されている。実際にアレルギー性鼻炎患者の 10 〜 40\%に喘息を，喘息患者の $20 ８ 0 \%$ にアレルギー性 鼻炎の合併を認めている2．そのため, アレルギー性鼻 炎の病態を考える上で, 上気道と下気道を一連の構造と して考える, “One airway, one disease” の概念の本質的 な理解が必要である。本稿では，上，下気道に共通す る病態として気道過敏性に焦点を当て, 過敏性光進の 機序として知られている最小持続炎症 (minimal persistent inflammation; MPI) について概説する。また，その病態 に合った初期治療や，唯一のアレルギー性鼻炎の根治療 法と言われるアレルゲン免疫療法について述べたい.

アレルギー性鼻炎と同㥞に下気道疾患と関連があり, 近年増加傾向の疾患に好酸球性副鼻腔炎 (Eosinophilic chronic rhinosinusitis; ECRS) がある. ECRS は2001 年に 初めて春名ら ${ }^{3)} に よ り$ 提唱された疾患概念で, 鼻腔内に 扔ける鼻茸の存在，末梢血扔よび鼻茸組織中の好酸球数 増多を特徴とする。手術と薬物療法が治療の軸となるが,
再発率が高く病勢の安定化には難渋する疾患である。本 稿では ECRS の病態や治療法についても概説したい.

\section{1. アレルギー性鼻炎}

アレルギー性鼻炎は最も罹患率の高い疾患であり，本 邦に扔いて国民病の一つである。2008 年に行われたア レルギー性鼻炎の全国アンケート調査では, アレルギー 性鼻炎全体の有病率は39.4\%であり, 1998 年に行われ た同じ調査では $29.8 \%$ であり，10 年間で $10 \%$ も増加し ている ${ }^{4)}$. 病態としてI 型アレルギーによる抗原抗体反 応および抗原特異的 IgE 産生, 肥満細胞などの炎症細胞 からのケミカルメディエーターの産生による鼻粘膜局所 の炎症を引き起こす。くしゃみ, 鼻汁, 鼻閉を主訴とし 生活の質 (quality of life; QOL) を著しく低下させ，それ に伴う労働生産性低下による一人当たりの経済的損失は 年間で 191,783 円と言われている5).

\section{1-1. アレルギー性鼻炎の病態と過敏性元進}

気管支喘息を診断する上で，気道過敏性の重要性が指 摘されている。しかし，アレルギー性鼻炎の診断は症状 と検查 (Table 1) のみでされ, 直接的な気道過敏性を評 価する項目が存在しない。しかし，アレルギー性鼻炎 の重症化や難治化には鼻粘膜過敏性の克進揖よび鼻汁 中の好酸球の増加が重要である゙ 
Table 1 Diagnosis of allergic rhinitis

\begin{tabular}{|c|c|}
\hline 1. 症状 & $\begin{array}{l}\cdot \text { くしゃみ（鼻のかゆみ） } \\
\cdot \text { ·水様性）鼻漏 } \\
\cdot \text { 鼻閉 }\end{array}$ \\
\hline 2. 検査 & $\begin{array}{l}\text { ·皮膚テスト（または血清 } \operatorname{IgE} \text { 抗体検査） } \\
\text { ·鼻汁好酸球検査 } \\
\text { ·誘発テストト }\end{array}$ \\
\hline \multicolumn{2}{|c|}{$\begin{array}{l}\text { 診断 } \\
\text { 1. 症状の } 3 \text { 主徵 }+2 . \text { 検査のうち } 2 \text { つ上陽性 } \\
\text { 1. 症状の } 3 \text { 主徵 }+2 . \text { 検査のうち } 1 \text { つのみ陽性で, アレル } \\
\text { ギー検査が中等症以上 }\end{array}$} \\
\hline
\end{tabular}

文献 4 から引用，改編。

は，特異的抗原刺激（スギやダニなど抗原性をもつ物 質）に対してだけではなく, 非特異的刺激（冷気吸入や 粉塵吸入など）に対しても過敏に反応する。この過敏性 克進は繰り返される抗原暴露刺激によって誘導される. 近年ではその機序として最小持続炎症 (minimal persistent inflammation; MPI) が注目されている,8).

\section{1-2. MPI とアレルギー性鼻焱の治療}

MPI の状態 (Fig. 1) とは, アレルギー性鼻炎の症状出 現の準備段階といえる。抗原曝露がなく, 鼻粘膜障害や 炎症細胞浸潤がほとんど見られない正常な状態において, 反復する抗原曝露を受けると，アレルギー性鼻炎即時相 における肥満細胞浸潤のみならず，遅延相における好酸 球や好中球などの炎症細胞浸潤が起こるとともに, 細胞 の活性化がみられる。ささらに鼻粘膜上皮では，杯細胞や 分泌腺の過形成, 基底膜の肥厚や線維芽細胞による組織 のリモデリングが起こる。これらの炎症細胞浸潤や鼻粘 膜上皮の構造変化によって, 局所の慢性炎症の病態が完 成するとともに，抗原特異的な刺激のみならず非特異的 な刺激でも症状を引き起こす, 過敏性が元進した状態と なる、つまり，鼻汁，〈しゃみなどの症状が出現し，反 復している場合はMPIがすでに完成している段階であ る.ダニ，八ウスダストなどを抗原とする通年性アレル ギー性鼻炎では，基本的に抗原刺激に対して一年を通し て暴露されていることになり, 症状が無くても常にMPI の状態にあると考えられている ${ }^{8)}$ ，実際に，日常的に鼻 漏や鼻閉といった鼻炎症状の訴えが無く，視診上，鼻粘 膜の蒼白腫脹が高度で重症のアレルギー性鼻炎と思われ た患者が，寒暖差刺激や粉塵の吸入などの刺激があって 初めて, 鼻炎症状, 咽喉頭違和感, 咳症状を主訴として 受診することがある。これは，MPIによる粘膜の過敏性 六進により，生活環境において日常的に暴露している非 特異的な刺激で症状の発現をきたしたと考えられる。

アレルギー性鼻炎の治療は，抗原の回避を徹底した上 で，薬物療法を行い患者の QOL を向上させることが目 標となる ${ }^{4)}$. MPI の概念を治療に応用する上で，抗原の 回避は言うまでもない. 鼻アレルギー診療ガイドライン

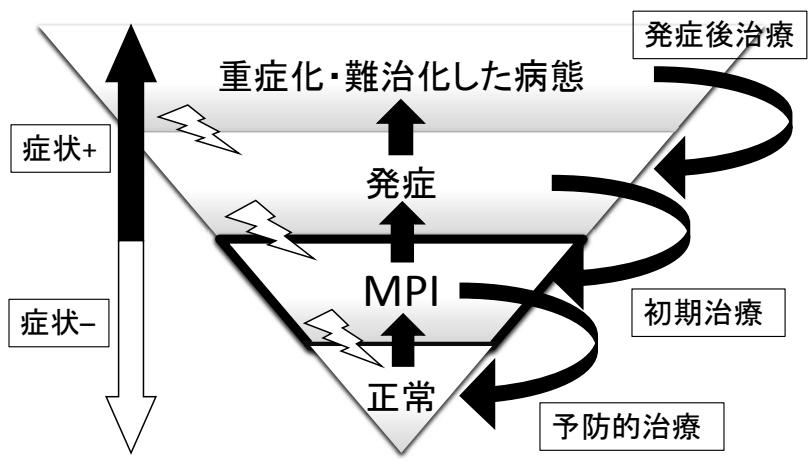

Fig. 1 Minimal persistent inflammation and therapy

では, 重症度に応じた治療法の選択が推奨されているが． 特に，第二世代抗ヒスタミン薬，ロイコトリエン受容体 拮抗薬，鼻噴霧ステロイド薬はアレルギー性鼻炎治療の key drug となる. MPI の制御という観点に扔けるそれぞ れの薬物の効果についての報告がある。抗ヒスタミン薬 はアレルギー性鼻炎の早期相に扔ける症状の改善がメイ ンであり，慢性化したMPIの状態には即効性は期待で きないが， 1 〜 ケ月連用した場合，頓服使用と比較し 局所の炎症細胞浸潤は抑制される9)。ロイコトリエン受 容体拮抗薬は，アレルギー性鼻炎の遅延相で血管内皮細 胞や浸潤細胞（好酸球，肥満細胞，好中球など）に発現 するシスチニルロイコトリエン受容体に作用し，血管透 過性㐫進を抑制し鼻閉の改善や，局所細胞浸潤の抑制が 期待できる ${ }^{10)}$ 。好酸球浸潤の抑制はMPI の制御に寄与 する作用と考えられる9! 鼻噴霧用ステロイド薬は，粘 膜に浸潤する炎症細胞のみならず，上皮細胞や分泌腺な ど粘膜を構築する細胞に対しても幅広い抗炎症作用を有 する ${ }^{11)}$ ，鼻噴霧ステロイド薬は，アレルギー性鼻炎の早 期相, 遅延相両方に作用し, 鼻粘膜の慢性炎症への誘導 を抑制する効果が期待できる。局所投与であり，副作用 を心配せず使用できるという点からも長期に使用するこ とで，MPI の病態を制御する上で有用な選択と言える. スギ花粉症に抒ける飛散前からの鼻噴霧ステロイド初期 治療開始群掞よび，飛散後からの鼻噴霧ステロイド開始 群では，ともにプラセボと比較し有意に症状抑制がみら れたと報告されており ${ }^{12)}$ ，鼻噴霧ステロイド薬は初期治 療から重症化したアレルギー性鼻炎にも有用であると考 えられる。

\section{1-3. アレルゲン免疫療法}

アレルゲン免疫療法は，アレルギー性鼻炎の自然経過 を改善させうる治療として期待される治療法である，以 前は減感作療法とも呼ばれていたが，近年では英語名で 統一されアレルゲン免疫療法と呼ばれるようになった。

日本では 1963 年にハウスダストの診断・治療エキスが 発売され，皮下免疫療法 (subcutaneous immunotherapy; SCIT) が開始された。近年ではアナフィラキシーショッ 
Table 2 Adverse events and its percentage

\begin{tabular}{|c|c|c|c|c|c|c|c|c|}
\hline \multicolumn{3}{|c|}{ 口腔咽頭症状 } & \multicolumn{3}{|c|}{ 鼻, 眼症状 } & \multicolumn{3}{|c|}{ その他 } \\
\hline & ダニ SLIT & スギ SLIT & & ダニ SLIT & スギ SLIT & & ダニ SLIT & スギ SLIT \\
\hline 口内局所浮腫 & 24 例 $(37.5 \%)$ & 8 例 $(11.6 \%)$ & 鼻閉 & 4 例 $(6.3 \%)$ & 6 例 ( $8.7 \%)$ & 耳そう痒感 & 2 例 $(3.1 \%)$ & 15 例 $(21.7 \%)$ \\
\hline 口腔内そう痒感 & 14 例 $(21.9 \%)$ & 17 例 $(24.6 \%)$ & くしゃみ & 1 例 $(1.6 \%)$ & 7 例 (10.1\%) & 皮膚そう痒感 & & 3 例 ( $4.3 \%)$ \\
\hline 口腔内刺激感 & 9 例 (14.1\%) & 9 例 (13.0\%) & 鼻漏 & 1 例 (1.6\%) & 3 例 ( $4.3 \%)$ & 下痢 & 2 例 (3.1\%) & 1 例 ( $1.4 \%)$ \\
\hline 口内炎 & 2 例 ( $3.1 \%)$ & 3 例 ( $4.3 \%)$ & 眼そう痒感 & & 8 例 (11.6\%) & 腹部不快感 & 1 例 (1.6\%) & 2 例 ( $2.9 \%)$ \\
\hline のどの不快感 & 8 例 (12.5\%) & 10 例 $(14.5 \%)$ & & & & 咳嗽 & 1 例 $(1.6 \%)$ & 3 例 ( $4.3 \%)$ \\
\hline
\end{tabular}

ダニ SLIT 全副反応 $42 / 64$ 例 $(65.6 \%)$

スギ SLIT 全副反応 39/69 例 (56.5\%)

文献 17, 18 から引用, 改編.

クなど重篤な合併症が少ないといった安全面から舌下免 疫療法 (sublingual immunotherapy; SLIT) が主流となりつ つある。 2014 年からスギ花粉舌下液 (シダトレン ${ }^{\circledR}$ ), 2015 年からダニ舌下錠 (ミティキュア ${ }^{\circledR}$, アシテア ${ }^{\circledR}$ ) 2018 年からスギ花粉舌下錠（シダキュア ${ }^{\circledR}$ ) が発売され 全国的に使用されるようになった。対象はシダトレンは 12 歳以上，他舌下錠は年齢制限なく処方できる（一般 には 5 歳以上が目安)。投与スケジュールはシダトレン ${ }^{\circledR}$,

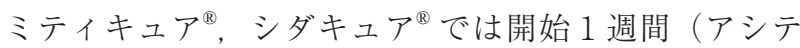
$ア^{\circledR}$ は投与開始 3 日間）は低用量で開始し，その後は維 持量として 1 日 1 回, 舌下投与を一般的に $3 \sim 5$ 年間施 行することが望ましいとされている ${ }^{13)}$.

治療開始後の臨床的有用性持続期間として Marogna $ら^{14)}$ はハウスダスト単独感作のアレルギー性鼻炎患者 をプラセボ群と, SLITの治療継続期間 3 年群, 4 年群, 5 年群の合計 4 群に分けた検討で, 4 年間 SLIT を施行 するのが最も適切と報告している。治療継続期間が長い ほど，投与終了後の症状抑制期間は長いと考えられてい るが，長期的な経過観察を施行した報告はなく，今後の 検討課題である。実際の鼻症状に対する有効性として， 免疫療法実薬群では症状ピーク時期における鼻症状（く しゃみ, 鼻漏, 鼻閉) スコア, 鼻症状薬物スコア（レス キュー薬の使用頻度を加味したスコア）ともにプラセボ 群と比較して統計学的に有意に症状を抑制していた ${ }^{15)}$.

一般的にアレルゲン免疫療法の有効性としては, ダニで は 80〜90\%，スギ花粉では 70\%前後と言われている ${ }^{4)}$. 眼症状に関しても症状スコアの有意な抑制がみられ ${ }^{15)}$, 有用性の報告がされている。坚においてダニによるア レルギー性鼻炎罹患児の，アトピー型喘息発症に高い割 合で寄与することが報告されているが ${ }^{16)}$ ，小児期からの ダニアレルゲンの除去と並行して SLIT 開始により，ア トピー型喘息発症リスクの軽減が今後期待される。

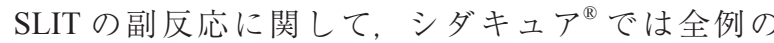
$56.5 \%$ ，ミティキュア ${ }^{\circledR}$ では全例の $65.6 \%$ に認められた と報告されている ${ }^{17,18)}$ 。高い副反応発現率ではあるが, ほとんどが局所的な副反応 (Table 2) であり，口腔咽頭 症状（局所浮腫, 口腔そう痒感, 刺激感, 不快感, 口内
炎), 鼻症状 (鼻閉, 〈しゃみ, 鼻漏), その他 (耳そう 痒感，咳嗽，胃不快感，下痢）などである。これらの症 状は，投与開始時や増量期にみられるのみで経過観察で 消失することが多く，持続的に症状を認める症例は少な い.アナナィラキシーの副反応は極めて稀であるが, 約 1 億回の投与に 1 回ほどの確率で起こるとされてお り ${ }^{19)}$ ，小巟や高齢者，重症なアレルギーをもつ者，呼吸 器, 心疾患など合併症をもつ者, 運動選手や日常的にス トレスの多い者，飲酒習慣のある者などリスク因子をも つ患者では慎重な適応決定，経過観察が必要である。

\section{1-4. アレルギー性鼻炎に対する手術療法と抗体療法}

薬物療法に反応しづらい鼻閉症状に対しては，手術治 療が推奨される。手術療法には鼻粘膜凝固術（レーザー 治療), 下鼻甲介切除術, 後鼻神経切断術, 鼻中隔矯正 術などがあり，画像検査やアレルギー検査を施行した上 で適切な術式が選択される。鼻腔内においてアレルギー 反応の主座となる鼻甲介粘膜には，(1)加温，加湿，整流 などの空気清浄機能, (2)繊毛運動による異物排除機能, (3)免疫グロブリン（IgA な゙）の分泌による感染防御機 能といった役割がある。手術治療ではこの鼻甲介に侵襲 を加えることになり, (1)〜3)の機能障害を十分に考慮し, 手術適応を十分に検討するべきである.

2019 年 12 月から抗 $\operatorname{IgE}$ モノクローナル抗体製剤ゾレ ア ${ }^{\circledR}$ (Omalizumab) が季節性アレルギー性鼻炎に対して適 応となった。最適使用推進ガイドライン ${ }^{20)}$ では，適応 として血清特異的 $\operatorname{IgE}$ 抗体がクラス 3 以上の季節性アレ ルギー性鼻炎で，抗原の回避の徹底，薬物療法による治 療を十分に行ったものの, コントロール不十分な鼻症状 （くしゃみ，鼻汁及び鼻閉のすべての症状が出現し， か つ，そのうち 1 つ以上の症状について，鼻アレルギー診 療ガイドラインに基づく程度が +++ 以上であること.) が 1 週間以上持続している 12 歳以上の症例とされてい る。生物製剤による分子標的治療は, 重症喘息と同様に アレルギー性鼻炎に対しても病態に基づいた治療法であ り，今後のさらなる発展が期待される。 


\section{2. 慢性副鼻腔炎と好酸球性副鼻腔炎}

3ヶ月以上鼻閉, 鼻漏, 後鼻漏, 咳嗽といった呼吸器 症状が持続するものを慢性副鼻腔炎と定義する，慢性副 鼻腔炎は鼻腔形態異常により副鼻腔と固有鼻腔の交通が 遮断されることにより, 副鼻腔の感染が遷延化すること で病的粘膜の増生が起こることで慢性化した病態が形成 される。治療法としては，マクロライド少量長期療法が 60〜80\%の割合で奏功すると報告されている ${ }^{21)}$. 薬物療 法抵抗性の症例でも鼻内手術を併施することで完治が見 込まれる。しかし，1990年代から慢性副鼻腔炎患者の うちマクロライド療法および鼻内手術に抵抗性の症例 が報告されるようになり，2001 年に春名らによって好 酸球性副鼻腔炎 (Eosinophilic chronic rhinosinusitis; ECRS) の概念の提唱がなされた 共同大規模疫学研究 (Japanese Epidemiological Survey of Refractory Eosinophilic Chronic rhinosinusitis Study; JESREC Study) が行われ，JESREC スコアに基づく臨床的な診断 基準が作成された (Table 3) 22) 。両側性の鼻茸 (Fig. 2a), CT で篩骨洞優位の副鼻腔炎陰影 (Fig. 2b), 末梢血好酸 球比率の值で診断できる。確定診断は組織生検で, 組織 中好酸球浸潤 (Fig. 2c) が 400 倍視野で 70 個以上認める 必要がある。臨床的特徵として, 多くが成人期以降に発 症し, 病早期から嗅覚障害, 鼻茸に伴う両側鼻閉, 非常 に粘性の高い鼻汁（ニカワ状分泌物）などの鼻症状を認
Table 3 Diagnosis of eosinophilic chronic rhinosinusitis based on JESREC study

\begin{tabular}{|llr|}
\hline$\cdot$ 病側 & 両側性 & 3 点 \\
$\cdot$ 鼻茸 & あり & 2 点 \\
$\cdot$ CT 陰影 & 篩骨洞 $\geqq 上$ 顎洞 & 2 点 \\
$\cdot$ 本梢血好酸球 & $2<\leqq 5 \%$ & 4 点 \\
& $5<\leqq 10 \%$ & 8 点 \\
& $10 \%<$ & 10 点 \\
\hline
\end{tabular}

合計点数が 11 点以上を好酸球性副鼻腔炎と診断する.

確定診断は，鼻茸組織中の好酸球浸潤が 400 倍 3 視野平均で 70 個以上.

文献 22 から引用，改編.

め，約半数の症例に気管支喘息の合併を認める。本邦の 罹患患者数は 20 万人に及ぶと言われており ${ }^{23)}, 2011$ 年 には厚生労働省指定難病となった。

\section{2-1. 好酸球性副鼻腔炎 (ECRS) の病態}

ECRS は鼻腔内における再発性の鼻茸を特徴とするが, 鼻茸再発の原因として従来の感染に引き続いて起こる慢 性副鼻腔炎とは異なり, type2 型の免疫反応（Th2 型反 応）によって好酸球性炎症が起こると考えられている. I 型アレルギー疾患であるアレルギー性鼻炎においても 好酸球炎症はみられるが, ECRS における好酸球性炎症 は高度であり，I型アレルギー単独でおこる炎症とは考 えにくい，実際にECRS の手術症例で，末梢血好酸球数

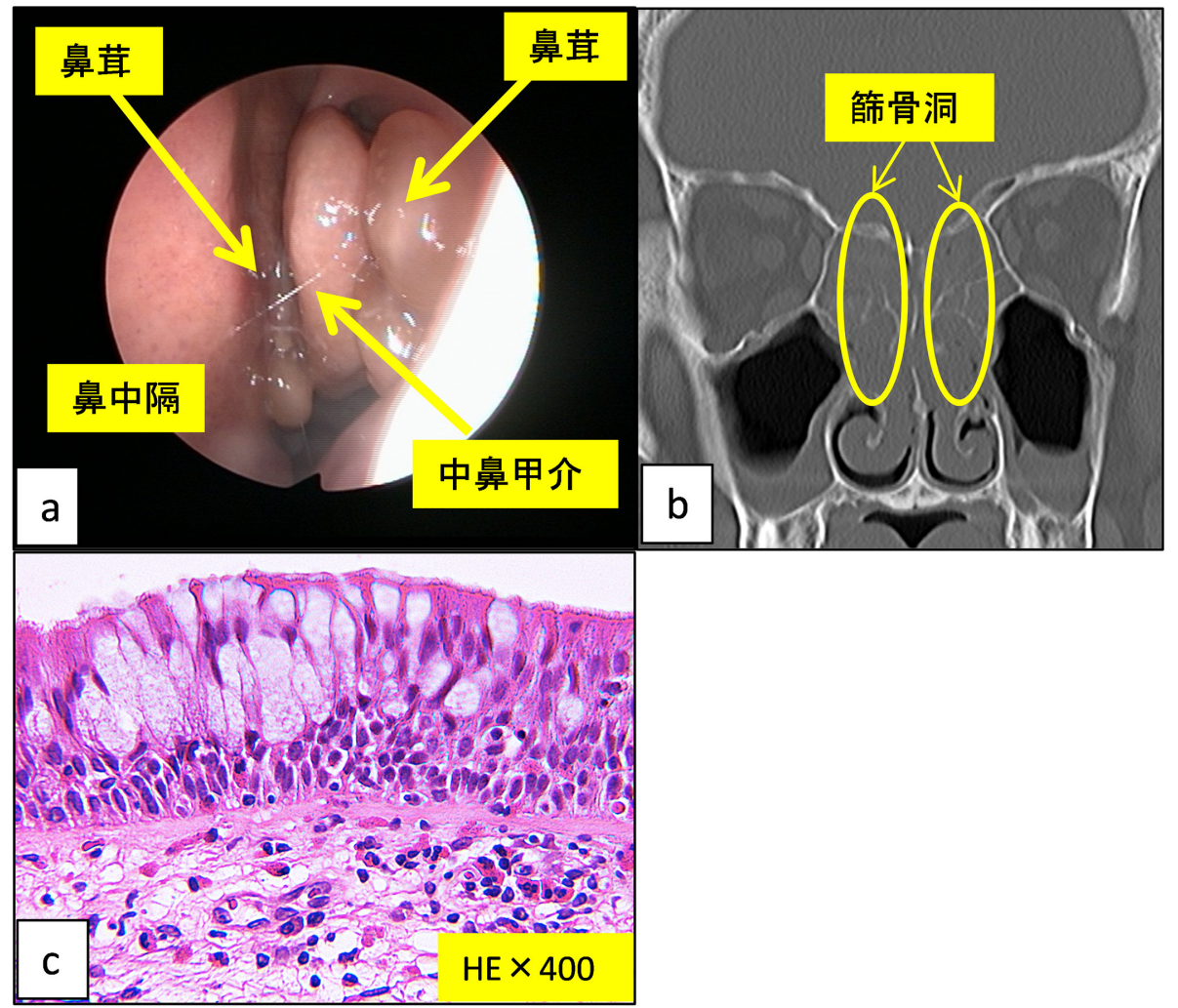

Fig. 2 Nasal endoscopic findings (a), CT findings (b) and histopathological findings of nasal polyp (c) of eosinophilic chronic rhinosinusitis. 
および組織中好酸球浸潤を高度に認める患者において, 特異的，非特異的 $\operatorname{IgE}$ 值の上昇は必ずしも認められるわ けではなく，I型アレルギー以外の病態の存在が疑われ る。近年，成人発症の気管支喘息において，I型アレル ギー反応を介さない Th2 型反応が確認されており，そ の原因として自然免疫反応の関与が示唆されている ${ }^{24)}$. 好酸球浸潤が著明な慢性副鼻腔炎においても同様の自然 免疫反応を介した病態モデルが報告されている ${ }^{25)}$ 。自然 免疫反応の機序として, 鼻粘膜上皮に外来環境からの刺 激として細菌，真菌，ウイルスの感染や抗原に含まれる プロテアーゼにより刺激を受けると，粘膜上皮から IL25, IL-33, thymic stromal lymphopoietin (TSLP) などの上 皮由来サイトカインの産生が起こり，2 型自然リンパ球 (Group 2 innate lymphoid cells: ILC2) に作用し，そこから IL-4, IL-5, IL-13 といった Th2 サイトカインの産生が起 こることにより，局所の好酸球浸潤や IgE 産生や組織の リモデリングを起こす (Fig. 3). ILC2 は細胞表面に T 細 胞受容体も B 細胞受容体も発現しておらず，抗原抗体 反応を必要とせず, 細胞 1 個あたりで $\mathrm{T}$ 細胞の数百倍

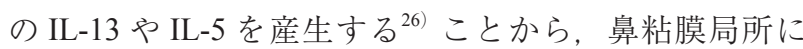
高度な好酸球性炎症を誘導することができる，炎症が起 きた鼻腔は狭く，もともと副鼻腔の蜂巣構造は複雑であ ることから，粘膜上皮表面に与える外因性刺激は持続的 となりやすく，粘膜上皮における炎症は遷延しやすいこ とが想像される。ECRS の鼻茸再発に関しては，自然免 疫反応を介した機序の他にも様々な検討がなされている が，定説はまだなく今後の研究に期待される。

\section{2-2. 好酸球性副鼻腔炎 (ECRS) の治療}

ECRS の治療は，手術による病変の除去および副鼻腔 形態の整復, 局所治療による厳重な術後経過観察が中 心となる。手術は内視鏡下鼻内副鼻腔手術 (endoscopic sinus surgery: ESS) が一般的である。ESS の実際の手技 は，鼻腔内の鼻茸を除去したのち，副鼻腔の単洞化を行 うことが目標となる。副鼻腔の構造は篩骨洞を中心とし ており，篩骨洞と中鼻道は他の副鼻腔（上顎洞，前頭 洞，蝶形洞）との中継地点および排泄経路の拠点となっ ている。ECRS では複䧱な篩骨洞の構造の内部に鼻茸様 の病的粘膜や多量の好酸球由来の炎症性サイトカインを 含んだムチの充満がみられ，前述の外因性刺激となる 細菌やプロテアーゼの停滞や慢性炎症を引き起こす原因 となる，ESSによって篩骨洞の完全な開放および他の副 鼻腔との交通を十分につけ単洞化することで，好酸球性 炎症の主座をとなる複雑な副鼻腔構造の改善が見込まれ る。

術後治療としては，ESS で開放した副鼻腔構造の維持 が重要となる。重症の ECRS では，術後 6 年で約 $50 \%$ の症例で副鼻腔内の鼻茸再発が見られたと報告されてい る る $^{23)}$ ESS 後は鼻洗浄を行うことにより副鼻腔内に貯留

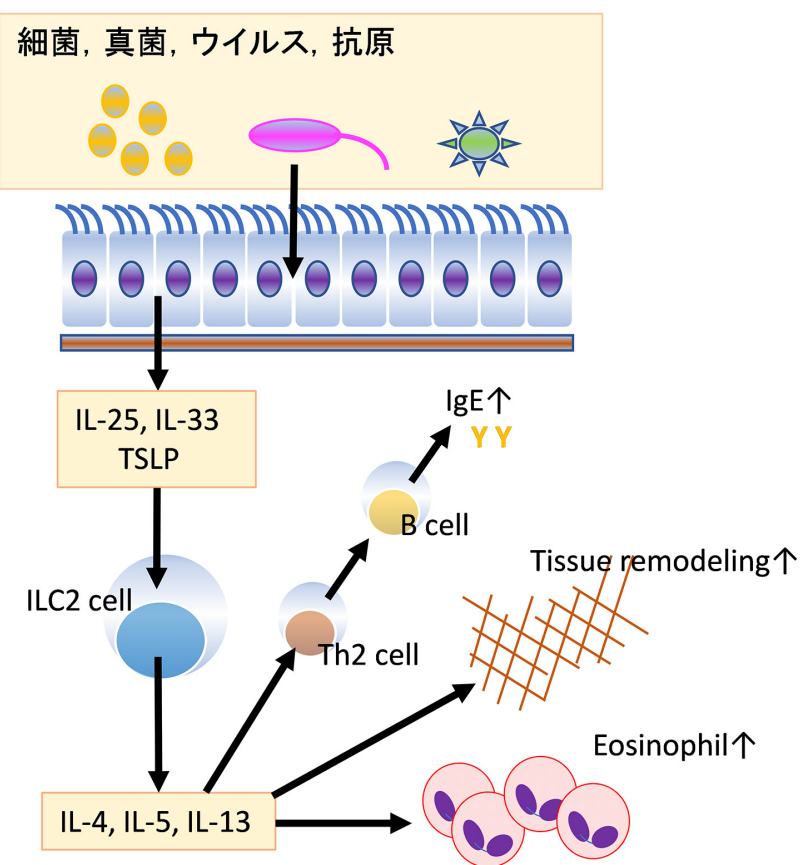

Fig. 3 Immune response model of eosinophilic chronic rhinosinusitis

した好酸球や炎症性サイトカインの洗い流しをしつつ, 薬物療法として, 経口および局所副腎皮質ステロイド薬, 抗ロイコトリエン薬, 抗生物質, 消炎酵素薬など投与が 重要となってくる。定期的に鼻所見を確認し, 病勢を評 価し, 可能な限り経口ステロイド薬を減らし炎症の鎮静 化を図る。また，現在，気管支喘息やアトピー性皮膚炎 だけでなくECRSに対しても抗体医療による分子標的治 療 (抗 IgE 抗体, 抗 IL-5 抗体, 抗 IL-5 受容体抗体, 抗 IL-4/13 抗体など）が臨床応用されつつある ${ }^{27)}$. 分子標 的治療は ECRS の病態を考慮すると, 効果的な治療と思 われるが, 高価な治療であり，短期的な効果ではなく長 期的な鼻茸再発抑制に効果があり，経口ステロイド薬に とって代わることができる治療となることが今後期待さ れる。

\section{最 後に}

アレルギー性鼻炎, 好酸球性副鼻腔炎はともに増加傾 向にある疾患であり，今後さらなる患者数の増加が予想 される。両疾患ともに病態を抑制することで二次的に起 こりうる下気道の病態の改善が期待できる。 上気道と下 気道には解剖学的な構造の違いはあるが, 気道粘膜で起 きている病態生理に共通する部分が多く, 局所的に疾患 に対してアプローチするのではなく一つの気道として病 態を克服する必要性があると考えられる。

本論文において開示すべき COI はありません. 


\section{文献}

1) Allergic rhinitis and its impact on asthma. J Allergy Clin Immunol 2001; 108(5 Suppl): S147-334. Review. WHO position paper.

2) Okano M, Kariya S, Ohta N, et al. Association and management of eosinophilic inflammation in upper and lower airways. Allergol Int 2015; 64(2): 131-138.

3）春名眞一, 鴻 信義, 柳清, 他. 好酸球性副鼻腔炎 (Eosinophilic Sinusitis)。耳鼻展望 2001; 44(3): 195-201.

4）鼻アレルギー診療ガイドライン作成委員会: 鼻アレルギー 診療ガイドラインー通年性鼻炎と花粉症-2016 年版（改 訂第 8 版)。ライフサイエンス, 2016.

5）岡本美孝。鼻閉を伴うアレルギー性鼻炎に係る経済的損 失. 医薬ジャーナル 2014; 50(3): 983-991.

6）奥田 稔. 鼻アレルギー一基礎と臨床：鼻粘膜過敏性立 進のメカニズム。2005 年版. 医薬ジャーナル社, 2005.

7) Canonica GW, Compalati E. Mininal persistent inflammation in allergic rhinitis: implications for current treatment strategies. Clin Exp Immunol 2009; 158(3): 260-271.

8) Ciprandi G, Buscaglia S, Pesce G, et al. Minimal persistent inflammation is present at mucosal level in patients with asymptomatic rhinitis and mite allergy. $J$ Allergy Clin Immunol 1995; 96(6 Pt 1): 971-979.

9) Ciprandi G, Ricca V, Passalacqua G, et al. Seasonal rhinitis and azelastine: long- or short-term treatment? J Allergy Clin Immunol 1997; 99: 301-307.

10) Shirasaki H, Kanaizumi E, Watanabe K, et al. Expression of the cysteinyl leukotriene 1 receptor in human nasal mucosa. Clin Exp Allergy 2002; 32: 1007-1012.

11) Okano M. Mechanisms and clinical implications of glucocorticosteroids in the treatment of allergic rhinitis. Clin Exp Immunol 2009; 158: 164-173.

12）春名成範, 岡野光博, 檜垣貴哉, 他. 新しい鼻噴霧用ス テロイド薬の使い方. ENTONI 2015; 180: 37-42.

13) Radulovic S, Calderon MA, Wilson D, et al. Sublingual immunotherapy for allergic rhinitis. Cochrane Database Syst Rev 2010(12); CD002893.

14) Marogna M, Spadolini I, Massolo A, et al. Long lasting effects of sublingual immunotherapy according to its duration: A 15- year prospective study. J Allergy Immunol 2010; 126: 969 975.

15) Okamoto Y, Okubo K, Yonekura S, et al. Efficacy and safety of sublingual immunotherapy for two seasons in patients with Japanese ceder pollinosis. Int Arch Allergy Immunol 2015; 166: $177-188$

16) Linneberg A, Nielsen NH, Frolund L, et al. The link between allergic rhinitis and allergic asthma: A prospective population-base study. The Copenhagen Allergy Study. Allergy 2002; 57: 1048-1057.

17）湯田厚司，小川由紀子，鈴木祐輔，他．スギ花粉舌下免 疫療法治療薬シダキュア ${ }^{\circledR} 69$ 例の初年度治療成績.アレ ルギー 2019; 68(8): 958-965.

18）湯田厚司，小川由紀子，神前英明，他. ダニアレルゲ ン舌下免疫療法 64 例の治療 1 年目の臨床検討。日耳鼻 2019; 122: 1516-1521.

19）寺田哲也. 舌下免疫療法の副作用対策. ENTONI 2016 193: 41-45.

20）最適使用推進ガイドライン オマリズマブ（遺伝子組 換え）（販売名：ゾレア皮下注用 $75 \mathrm{mg}$, ゾレア皮下注 用 $150 \mathrm{mg}$, ゾレア皮下注 $75 \mathrm{mg}$ シリンジ，ゾレア皮下注 $150 \mathrm{mg}$ シリンジ)〜季節性アレルギー性鼻炎〜令和元年 12 月 厚生労働省.

21) European position paper on rhinosinusitis and nasal polyp Long-term treatment with antibiotics in chronic rhinosinusitis. Rhinology 2005; supplement 18: 34-35.

22) Tokunaga $T$, Sakashita M, Haruna $T$, et al. Novel scoring system and algorithm for classifying chronic rhinosinusitis: the JESREC Study. Allergy 2015; 70(8): 995-1003.

23）藤枝重治, 坂下雅文, 徳永貴広, 他. 好酸球性副鼻腔炎: 診断ガイドライン (JESREC Study)。 日耳鼻 2015；118: $728-735$.

24) Kubo M. Innate and adaptive type 2 Immunity in lung allergic inflammation. Immunol Rev 2017; 278(1): 162-172.

25) Whitney S, Robert L, Robert $\mathrm{S}$, et al. Chronic rhinosinusitis pathogenesis. J Allergy Clin Immunol 2015; 136(6): 1442 1453.

26）松本健治. 自然リンパ球とアレルギー。アレルギー 2016; 65(3): 153-158.

27）吉川 衛。好酸球性副鼻腔炎とは。 ENTONI 2017；209: $1-7$. 